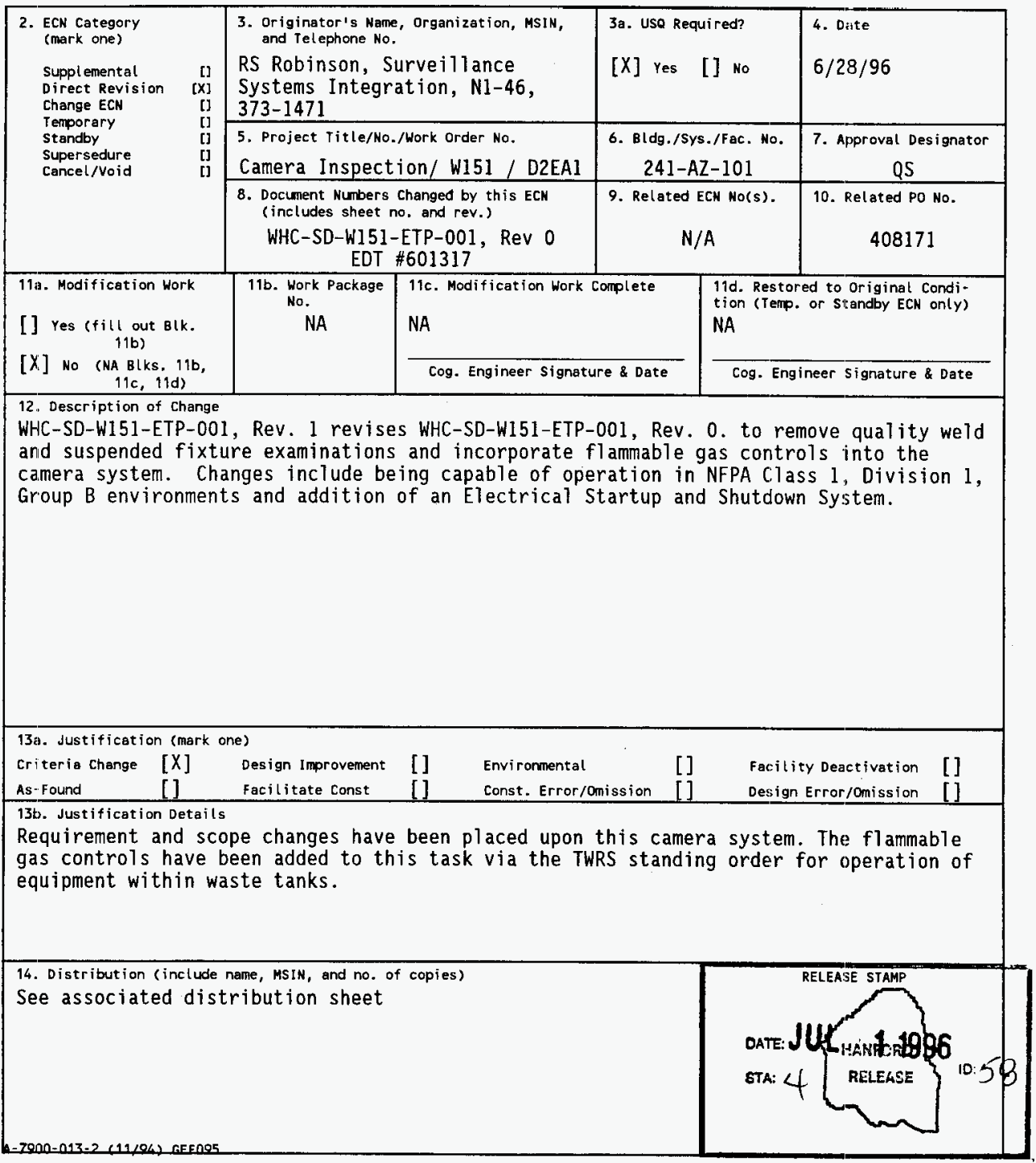




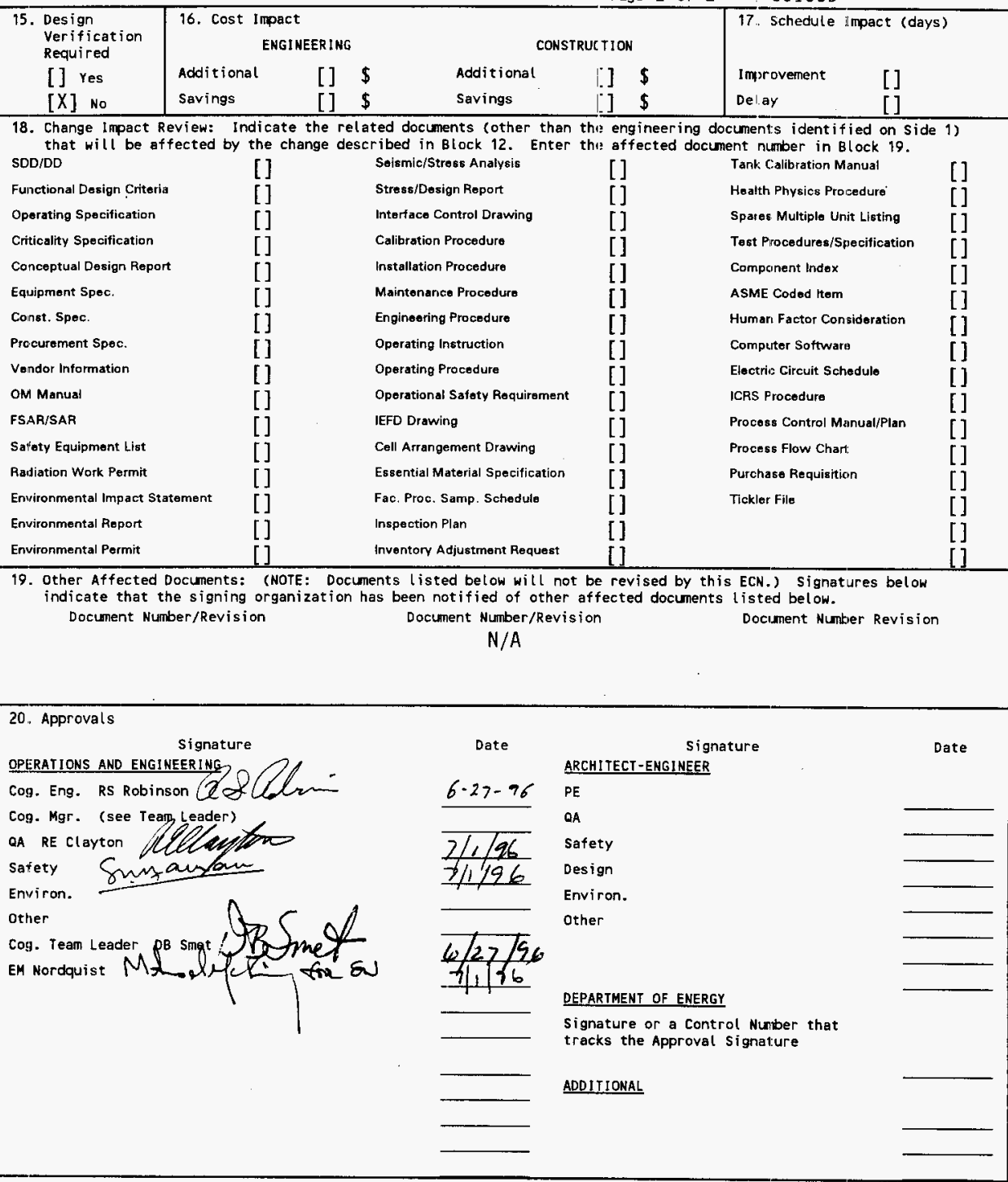




\section{ENGINEERING TASK PLAN FOR THE 241-AZ-101 WASTE TANK COLOR VIDEO CAMERA SYSTEM}

RS Robinson

Westinghouse Hanford Co., Richland, WA 99352

U.S. Department of Energy Contract DE-AC06-87RL10930

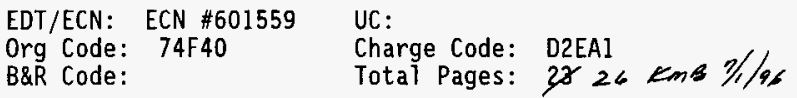

Key Words: camera, imaging system, 241-AZ-101

Abstract: This Engineering Task Plan (ETP) is to be distributed to communicate the design basis of the 241-AZ-101 camera system and to define system requirements and associated responsibilities.

TRADEMARK DISCLAIMER. Reference herein to any specific comercial product, process, or service by trade name, trademark, manufacturer, or otherwise, does not necessarily constitute or imply its endorsement, recommendation, or favoring by the United states Goverrment or any agency thereof or its contractors or subcontractors.

Printed in the United States of America. To obtain copies of this document, contact: WHC/BCS Document Control Services, P.O. Box 1970, Mailstop H6-08, Richland WA 99352, Phone (509) 372-2420; Fax (509) 376-4989.
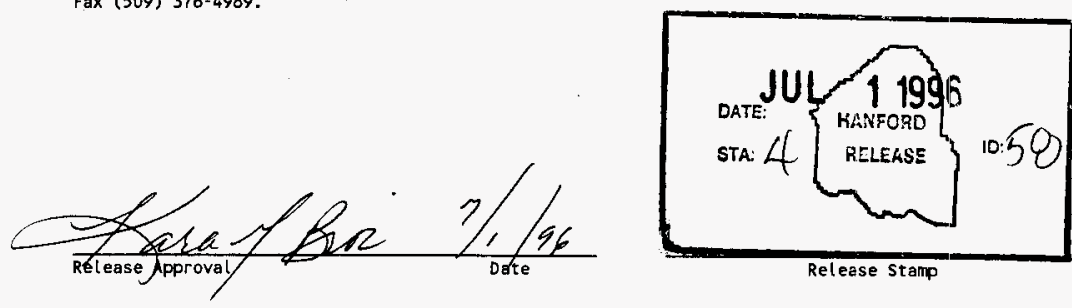

Approved for Public Release 
(2) Title

ENGINEERING TASK PLAN FOR THE 241-AZ-101 WASTE TANK COLOR VIDEO CAMERA SYSTEM

CHANGE CONTROL RECORD

\begin{tabular}{|c|c|c|c|}
\hline \multirow{2}{*}{ (3) Revision } & \multirow{2}{*}{ (4) Description of Change - Replace, Add, and Delete Pages } & \multicolumn{2}{|c|}{ Authorized for Release } \\
\hline & & (5) Cog. Engr. & (6) Cog. Mgr. \\
\hline 0 & $\begin{array}{l}\text { (7) WHC-SD-W151-ETP-001, Rev. } 0 \\
\text { originally released (EDT \#601317) } \\
\text { March 22, } 1995\end{array}$ & $\begin{array}{l}\text { RS Robinson } \\
\text { Original } \\
\text { signatures } \\
\text { on file }\end{array}$ & $\begin{array}{l}\text { DB Smet, } \\
\text { Origina1 } \\
\text { signatures on } \\
\text { file }\end{array}$ \\
\hline$R S^{1}$ & $\begin{array}{l}\text { WHC-SD-W151-ETP-001, Rev. 1 revises } \\
\text { WHC-SD-W151-ETP-001, Rev. 0. to remove } \\
\text { quality weld and suspended fixture } \\
\text { examinations and incorporate flammable gas } \\
\text { controls into the camera system. Changes } \\
\text { include being capable of operation in NFPA } \\
\text { Class 1, Division 1, Group B environments } \\
\text { and addition of an Electrical Startup and } \\
\text { Shutdown System. Per ECN } 601559\end{array}$ & RS Robinsan & $\begin{array}{l}\text { Team Leader } \\
\text { DB Smet }\end{array}$ \\
\hline & & & \\
\hline & & & \\
\hline & & & \\
\hline & & & \\
\hline & & & \\
\hline & & & \\
\hline & & & \\
\hline & & & \\
\hline & & & \\
\hline & & & \\
\hline & & & \\
\hline & & & \\
\hline & & & \\
\hline & & & \\
\hline & & & \\
\hline & & & \\
\hline & & & \\
\hline & & & \\
\hline & & & \\
\hline & & & \\
\hline & & & \\
\hline & & & \\
\hline & & & \\
\hline & & & \\
\hline
\end{tabular}


WHC-SD-W151-ETP-001, REV. 1

\title{
ENGINEERING TASK PLAN FOR THE 241-AZ-101 WASTE TANK COLOR VIDEO CAMERA SYSTEM
}

\author{
Approval Designator QS
}

Surveillance Systems Integration

Randall S. Robinson

June 27, 1996 


\section{TABLE OF CONTENTS}

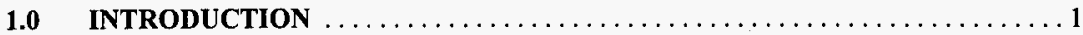

1.1 PURPOSE AND SCOPE $\ldots \ldots \ldots \ldots \ldots \ldots \ldots \ldots \ldots \ldots \ldots \ldots \ldots \ldots \ldots \ldots$

1.2 BACKGROUND $\ldots \ldots \ldots \ldots \ldots \ldots \ldots \ldots \ldots \ldots \ldots \ldots \ldots \ldots \ldots \ldots \ldots \ldots$

2.0 ORGANIZATION STRUCTURE AND RESPONSIBILITIES $\ldots \ldots \ldots \ldots \ldots 2$

2.1 DOUBLE SHELL TANK (DST) RETRIEVAL PROJECTS $\ldots \ldots \ldots \ldots \ldots 2$

2.2 SURVEILLANCE SYSTEMS INTEGRATION (SSI) $\ldots \ldots \ldots \ldots \ldots \ldots \ldots 2$

2.3 ICF KAISER HANFORD (ICF KH) ORGANIZATION $\ldots \ldots \ldots \ldots \ldots \ldots 4$

2.4 WHC SUPPORT ORGANIZATIONS $\ldots \ldots \ldots \ldots \ldots \ldots \ldots \ldots \ldots \ldots$

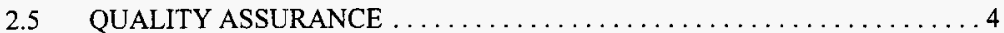

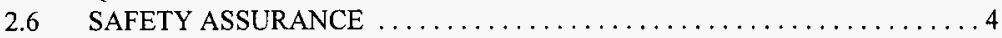

3.0 SURVEILLANCE ACTIVITIES DESCRIPTION $\ldots \ldots \ldots \ldots \ldots \ldots \ldots$

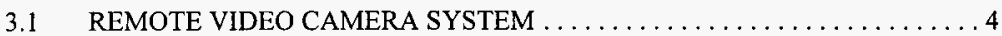

3.1 .1 FUNCTIONAL DESIGN CRITERIA $\ldots \ldots \ldots \ldots \ldots \ldots \ldots \ldots \ldots$

3.1 .2 SYSTEM SUMMARY $\ldots \ldots \ldots, \ldots \ldots \ldots, \ldots, \ldots, \ldots, \ldots$

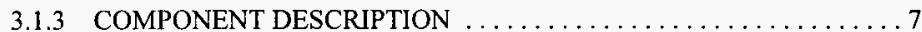

3.2 PRE-SURVEILLANCE REQUIREMENTS $\ldots \ldots \ldots \ldots \ldots \ldots \ldots \ldots \ldots$

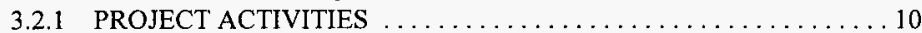

3.2.2 PERSONNEL TRAINING/QUALIFICATIONS $\ldots \ldots \ldots \ldots \ldots \ldots 11$

3.3 GENERAL SURVEILLANCE ACTIVITIES $\ldots \ldots \ldots \ldots \ldots \ldots \ldots \ldots 1$

3.4 POST-SURVEILLANCE ACTIVITIES $\ldots \ldots \ldots \ldots \ldots \ldots \ldots \ldots \ldots \ldots \ldots \ldots \ldots$

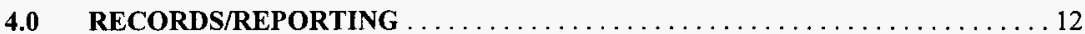

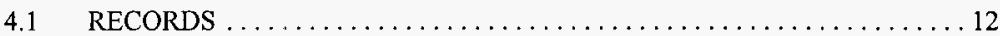

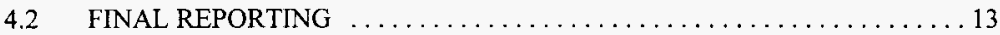

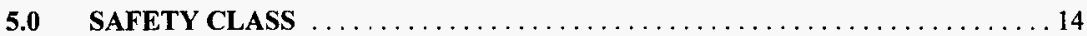

6.0 ALARA MANAGEMENT (PRINCIPLES/PRACTICES) $\ldots \ldots \ldots \ldots \ldots \ldots 14$

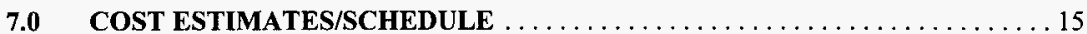

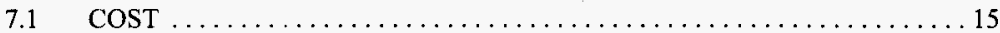

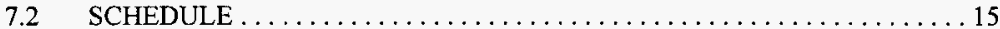

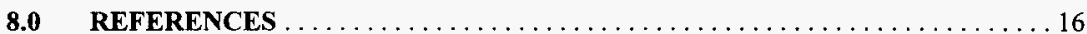

ETN-95-0038 
FIGURE 1. DRAWING OF CAMERA AND MAST ASSEMBLY $\ldots \ldots \ldots \ldots \ldots \ldots$

FIGURE 2. GENERAL SYSTEM CONFIGURATION $\ldots \ldots \ldots \ldots \ldots \ldots \ldots \ldots \ldots \ldots \ldots$

FIGURE 3. AVAILABLE VIEWING RISERS $\ldots \ldots \ldots \ldots \ldots \ldots \ldots \ldots \ldots \ldots \ldots$

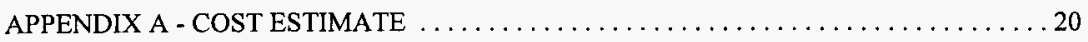

ETN-95-0038 


\section{ENGINEERING TASK PLAN FOR THE 241-AZ-101 WASTE TANK COLOR VIDEO}

\section{CAMERA SYSTEM}

\subsection{INTRODUCTION}

\subsection{PURPOSE AND SCOPE}

The purpose of this plan is to present a detailed description of management, installation and surveillance methods to be used to accomplish the upcoming remote visual surveillance of Tank 241-AZ-101 to support Project W151, Tank Waste Retrieval System. The camera system is scheduled to be installed by July 1996.

The objective of the camera system is to provide an overview of the tank during the mixing operations, using a fully shielded camera with prism optics. Radiation levels in the tank are currently too high to use a non-shielded camera to view the waste during mixing operations. The shielded camera will be capable of operating in the worst case, high radiation, environment. A second camera with high magnification capabilities will be used to view the tank dome. This second camera is not shielded in front of the lens and therefore will not be used to view the waste.

The Surveillance and installation activities shall be performed in the safest, most cost efficient, and ALARA conscious manner possible. This will necessitate establishment and training of a qualified work force, development and deployment of an appropriate surveillance system, and performance of visual surveillance utilizing remote CCTV equipment and conveyance of acquired information to the appropriate organization.

This plan provides:

- A brief review of the background for this activity.

- A description of the management structure, ALARA measures, safety structures and estimated cost/schedule for accomplishing these activities.

- Descriptions of the major elements of the project, including the remote video camera system, surveillance activities, and reporting requirements.

\subsection{BACKGROUND}

Waste tank 241-AZ-101 is the first tank planned to have its liquid/slurry waste mixed, in-tank, prior to pumping to the treatment plant. The mixing action from pumps is expected to produce hydrodynamic forces on in-tank fixtures. The camera system will provide visual information during these operations. 
Precautionary measures have been imposed on entry requirements for tank intrusive work. Equipment to be deployed in tanks are subject to flammable gas controls. This camera system shall be designed to the National Fire Protection Association (NFPA) Class 1, Division 1 Group $B$ requirements to ensure equipment qualification should safety controls become more conservative.

Waste tank 241-AZ-101 has a number of environmental characteristics which must be considered. The camera system, to provide the required information from within the tank vapor space, shall be uniquely designed to operate in a high radiation, high heat and flammable gas environment. The estimated radiation field within the tank is 1100 $\mathrm{Rad} /$ hour with "hard gamma" energy similar to Cesium-137 (0.667 Mev). Maximum anticipated temperature in the tank during mixing is $93^{\circ} \mathrm{C}\left(200^{\circ} \mathrm{F}\right)$.

\subsection{ORGANIZATION STRUCTURE AND RESPONSIBILITIES}

Surveillance Systems Integration (SSI) will be responsible for directing the surveillance activities to completion within guidelines specified in this task plan. Support organizations identified in this plan will provide all ancillary support necessary to ensure successful completion of these activities. All organizations will be responsible for establishing the scope of work for each of their respective areas of concern and oversight responsibility.

Functional responsibilities for the personnel and organizations will be as stated in this section.

\subsection{DOUBLE SHELL TANK (DST) RETRIEVAL PROJECTS}

DST Retrieval Projects will serve as the Responsible Manager and Engineer for the overall project. DST Retrieval Projects shall provide SSI personnel with guidance pertinent to installation and establishing surveillance requirements and criteria. DST Retrieval Projects shall provide budget, schedule requirements and funding for this activity.

\subsection{SURVEILLANCE SYSTEMS INTEGRATION (SSI)}

Surveillance Systems Integration (SSI) Team Lead and Engineer shall be accountable to the DST Retrieval Projects Responsible Manager and Engineer. SSI Team Lead and Engineer will be responsible for all activities associated with the camera system. Interfacing with related activities is also the responsibility of this organization.

Specific SSI camera system duties and responsibilities include but are not limited to:

2.1.1 Design of the camera system.

ETN-95-0038 
2.1.2 Provide Functional Design Criteria (FDC) for the camera system to Engineering Task Plan (ETP) and to the procurement specifications.

2.1.3 Provide comment resolution, input and support during design reviews on the camera systems.

2.1.4 Provide procurement documentation, including any sole source justifications required to expedite procurement, and perform all review and comment resolutions.

2.1.5 Vendor interface for the procurement of surveillance camera equipment.

2.1.6 Provide design and oversight of Onsite/offsite fabrication and procurement of electrical shutdown system and required gas flow and cooling system components.

2.1.7 Provide input and interface with related activities such as containment (sleeving recommended), Quality Assurance requirements, safety and ALARA concerns, etc.

2.1.8 Provide input into required Environmental, Safety, or Quality Assurance assessments, and others.

2.1.9 Provide information and input to Unreviewed Safety Question (USQ) Screening.

2.1.10 Mockup and functional testing of the camera, control systems, electrical shutdown and gas pressurization system.

2.1.11 Provide coordination and direction during testing and examination of the camera systems and ancillary equipment.

2.1.12 Develop, coordinate, and conduct Acceptance Test Procedure/Operational Test procedure (ATP/OTP) documentation and related activities.

2.1.13 Provide guidance and direction to on site work and tank farm camera installation activities. Provide work package direction and assistance as required to ensure installation success.

2.1.14 Coordinate and control surveillance activities including: ensuring required training to personnel and coordination of the surveillance activities, in addition to storing and retaining required records. 
2.1.15 Provide engineering responsibility for the camera system and surveillance activities to be performed in this project. Maintain technical ownership of the camera system.

\subsection{ICF KAISER HANFORD (ICF KH) ORGANIZATION}

ICF KH may be required to provide support of the camera system installation of the camera system. Support operations to include PCP preparation, crane operations, camera installation support and other site activities.

\subsection{WHC SUPPORT ORGANIZATIONS}

200 East Area's Radiological Control, Operations, various crafts, transportation, and procurement, will be called upon to support the installation and surveillance activities as required.

\subsection{QUALITY ASSURANCE}

Will provide the appropriate reviews and support of documentation, procurement, and test plans/procedures.

\subsection{SAFETY ASSURANCE}

Will provide the appropriate reviews and support of documentation, procurement, and test plans/procedures. Assure ETF Radiological Control reviews and signs documentation and procedures as required.

\subsection{SURVEILLANCE ACTIVITIES DESCRIPTION}

\subsection{REMOTE VIDEO CAMERA SYSTEM}

\subsubsection{FUNCTIONAL DESIGN CRITERIA}

3.1.1.1 All in-tank electrical components shall be designed to meet the Class 1, Division 1, Group B (hydrogen) National Fire Protection Association (NFPA) requirements.

3.1.1.2 An electrical startup and shutdown system that meets the requirements for a safety class system shall be utilized. This system is currently available off the shelf as WHC qualified safety class equipment. 
3.1.1.3 The in-tank imaging component configuration shall be capable of being deployed through a minimum envelope as defined by a typical $10.2 \mathrm{~cm}\left(4^{\prime \prime}\right)$ schedule 40 riser.

3.1.1.4 All control functions are to be capable of remote operation at a

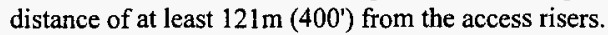

3.1.1.5 The in-tank imaging components shall have remotely controlled articulation capabilities for full tank viewing.

3.1.1.6 Two in-tank imaging cameras shall be provided: one is to provide fully shielded waste viewing capabilities with a ron-browning zoom lens and the second camera shall have a high magnification non-browning zoom lens capable of magnifying an image to appear five times larger than the actual size on the viewing monitor.

3.1.1.7 The light source shall be an integrated part of the imaging system and provide at least double the recommended scene illumination for quality images at $6 \mathrm{~m}\left(20^{\prime}\right)$ for the high magnification camera and $18 \mathrm{~m}\left(60^{\prime}\right)$ for the overview camera in a environment where the tanks walls and waste surfaces are dark brown to black in color.

3.1.1.8 The maximum operating temperature of all external surfaces shall not exceed $416^{\circ} \mathrm{C}\left(781^{\circ} \mathrm{F}\right)(80 \%$ of the auto-ignition temperature of hydrogen).

3.1.1.9 The high magnification imaging system shall be capable of resolving a $1 / 32$ inch black line on a card of $18 \%$ neutral gray background at a distance of 6.1 meters ( 20 feet) using only the light provided by the integrated light source..

3.1.1.10 The camera systems shall have a 1000 hour minimum useful life expectancy in the tank radiological and atmospheric conditions based on continuous operation or be designed with disposable components, with spare parts on hand. A minimum or $40: 1$ shielding factor is recommended.

In-Tank Design Conditions: The estimated radiation field within the tank is $1000 \mathrm{Rad} /$ hour with "hard gamma" energy similar to Cesium-137 (0.667 Mev). Maximum anticipated temperature in the tank is $93^{\circ} \mathrm{C}\left(200^{\circ} \mathrm{F}\right)$. 
3.1.1.11 A series gas flow path shall be provided from the upper junction box through the mast, pan-and-tilt unit, camera housing arid lights. This is a once through purge path (NFPA 496, Type X pressurization). Wiring and interface for two differential pressure switches are to be installed in the camera housing to monitor the pressure in the last enclosure in the gas flow path (light). Wiring for the differential pressure switches shall meet the Instrurnent Society of America, ANSI//SA-RP12.6-1987 for intrinsically safe system installations.

3.1.1.12 The camera system components which are deployed through the tank risers shall be designed for fail-safe removal.

3.1.1.13 Camera system components to be deployed into the tank vapor space shall have all external encasement made of 300 series stainless steel. All external materials used in the camera design which are to be located in the vapor space shall be compatible with the radiological and chemical constituents.

\subsubsection{SYSTEM SUMMARY}

The camera system consists of two camera assemblies containing a number of identical features. Two focused beam lights are located on each camera assembly. The lights will be mounted to the same assembly fixtures as the camera and pan-and-tilt so that they will track with the camera. One camera will be capable of high magnification viewing of riser, fixtures and the tank dome. The second camera will be designed to view the waste in the tank. This approach will enable the viewer to observe the subject under different lighting schemes and provide tank waste overview in addition to high magnification detailed inspection capabilities.

A series gas flow path has been provided from the upper junction box through the mast, pan-and-tilt unit, camera housing and lights. This is a once through flow path (NFPA 496, Type $X$ pressurization). Two differential pressure switches are installed in the camera housing to monitor the pressure in the last enclosure in the flow path (light). These pressure switches are to be monitored by an Electrical Startup and Shutdown System to meet the NFPA code requirements for operation in a Class 1, Division 1, Group B hazardous location. The electrical shutdown system shall meet the applicable WHC safety class requirements. The electrical startup and shutdown system will be connected to the camera system at the local field control unit. 
The integrated camera system (See Figure l) will function with sophisticated position and location indexing that will be displayed real time on the viewing monitor as the system is manipulated within the tank. The miniature color cameras will have shielding around the electric circuitry to reduce direct radiation exposure to meet the 1000 hour performance life, relative to radiation field, of the camera systems.

- The high magnification camera (Figure 2, Camera 1) shielding will only cover the sides and back of the CCD camera electronics. The camera CCD electronics will gain the full benefit of the shielding so long as it is pointing approximately $15^{\circ}$ up from horizontal. This camera is not capable of viewing the waste in the tank without image noise in the form of sparkle ( $300 \mathrm{R}$ and up). It is specifically designed to view the fixtures on the dome of the tank.

- The overview camera (Figure 2, Camera 2) will utilize a fully shielded viewing camera with $90^{\circ}$ prism optics to prevent direct radiation exposure to the camera electronics. This camera will be capable of viewing the tank waste directly.

Each camera will be deployed with their own mast assembly into the tank risers. The camera systems have been designed to fit into a $10 \mathrm{~cm}$ ( 4.0 inch) diameter vertical access port (riser). The camera masts are adjustable from 4.6 meters ( 15 feet) to 6 meters ( 20 feet) in length into risers. This allows flexibility in camera system placement in the tank vapor space. Pan-and-tilt units are mounted to the bottom of the masts, this will enable the camera to attain the optimal viewing angle to an object of interest.

The camera controls are capable of operating up to 121 meters (400 feet) away from the 241-AZ-101 tank. This allows operation of the cameras during the inspection from a radiation clean area.

\subsubsection{COMPONENT DESCRIPTION}

The following features will be incorporated:

3.1.3.1 High resolution color CCD image sensor 460 TV horizontal resolution - minimum sensitivity of approximately $15 \mathrm{lux}$.

3.1.3.2 High Magnification Camera: The camera electronics will be shielded with a minimum of $2.5 \mathrm{~cm}(1 ")$ of lead when the nonbrowning lens is pointing approximately $15^{\circ}$ up from the horizontal position. No shielding is to be provided directly to the front of the camera. Therefore, the camera must be angled up to gain the benefits of the shielding. 
A high magnification non-browning lens to provide a minimum of a 5:1 image magnification ratio at a range of 6 meters (20 feet) when using a $44.45 \mathrm{~cm}(17.5 \mathrm{inch})$ monitor. The lens will provide a 4:1 (140mm to $560 \mathrm{~mm}$ ) zoom range. Minimum focus distance 0.5 meters (19.7 inch). The camera is capable of remote, focus, iris and zoom functions.

3.1.3.3 Overview Camera: The camera electronics will be fully shielded with lead. A prism shall be used to allow indirect viewing directly at the tank waste. The non-browning zoom lens will provide viewing to a range of 18 meters ( 60 feet). The zoom lens will provide a $4: 1(22 \mathrm{~mm}$ to $90 \mathrm{~mm})$ range. Minimum focus distance is 0.5 meters ( 19.7 inch). The camera is capable of remote, focus, iris and zoom functions.

3.1.3.4 Construction - lights and clamps, polyurethane jacketed, radiationtolerant camera cables. Water resistant stainless steel camera housing designed for ease of decontamination.

Both masts and camera system components shall be constructed of 300 series stainless steel for ease of decontamination and corrosion resistance. The video mast systems will be designed to be operated in $10 \mathrm{~cm}$ ( 4 inch) diameter access risers. The mast will be designed to extend to variable lengths ( 4.57 meters ( 15 feet) to 6 meters ( 20 feet)). A variable length is required to control the distance the cameras extend into the tank vapor space.

Adapters will be constructed to allow the camera systems to operate in $10 \mathrm{~cm}(4 \mathrm{inch})$ and $15 \mathrm{~cm}(6 \mathrm{inch})$ diameter risers.

3.1.3.5 Two independently controlled lights on each video mast will provide redundant lighting. The lighting will provide double the minimum recommended illumination for the high magnification camera at a viewing range of 6 meters ( 20 feet) and 18 meters (60 feet) for the overview camera. The lighting units will pan and tilt automatically with the shielded cameras. Each lamp will thave independent lighting intensity control.

3.1.3.6 A precision rotate mechanism will be incorporated with a variable speed range. A positional feedback encoding system will provide digital display and an automatic pre-set feature allowing the camera to automatically rotate to a pre-selected position. The 
rotate motor assembly and encoder will be mounted outside the tank. Rotate range: 185 degrees $-\varnothing-185$ degrees. Angular feedback of one (1) degree of accuracy. The ability to zero out the camera encoder will be provided.

3.1.3.7 The pan-and-tilt mechanism will be designed such that no movement or drift will occur if all power is removed from the video inspection system.

3.1.3.8 Fail-safe features will be part of the camera system design to assure that the system can be removed from the riser in the event of pan-and-tilt drive motor failure, or complete power loss.

3.1.3.9 Radiation tolerance - All components, except the camera sensor module, and lights will be suitable for use in high gamma fields with a cumulative absorbed dose in excess of $10^{8}$ rads.

Both camera sensors will be housed in a sealed stainless steel module $7.6 \mathrm{~cm}$ ( 3 inch) in diameter. Lead shieiding material will be provided around the image sensor. The camera will be a dual unit device with the minimum of electronics at the camera head. Depending on the energy level of the waste and assuming a gamma field of $1000 \mathrm{rads} / \mathrm{hr}$. $(0.67 \mathrm{MeV})$, an estimated camera life of 2,000 hours can be expected. The camera lenses and electronics will be a modular replaceable unit, therefore in the event of camera failure or lens browning only the module itself would need to be replaced.

3.1.3.10 An environmental equipment enclosure will contain the motor control, encoding electronics, camera control unit, lighting power supplies with front panel function control switches and position indicators. The housing will be water tight and constructed to a minimum of NEMA 4 Standards.

3.1.3.11 A series gas flow path shall be provided from the upper jurction box through the mast, pan-and-tilt unit, camera housing and lights. This is a once through purge path (NFPA 496, Type X pressurization). Wiring and interface for two differential pressure switches are to be installed in the camera housing to monitor the pressure in the last enclosure in the gas flow path (light). Wiring for the differential pressure switches shall meet the Instrument 
Society of America, ANSI/ISA-RP12.6-1987 for intrinsically safe system installations.

3.1.3.12 Protective Cover Gas can be supplied using an air compressor or bottled Nitrogen. The gas supply will be located at the Local Control Unit.

3.1.3.13 An Electrical Startup and Shutdown System shall be procured which accommodates NFPA code requirements to qualify for operation in a Class 1, Division 1, Group B hazardous location . The Electrical Shutdown System meets the applicable WHC safety class requirements. This system controls the electrical power supplied to the camera system at the local control box.

3.1.3.14 Detailed documentation package and operational manual.

\subsection{PRE-SURVEILLANCE REQUIREMENTS}

\subsubsection{PROJECT ACTIVITIES}

Prior to deployment of the remote visual surveillance system to the field for use, the following activities must be accomplished:

3.2.1.1 Procurement of the camera system must be completed.

3.2.1.2 Acceptance Testing of the camera system in a clean facility. Containment to be used should be procured for this activity.

3.2.1.3 Operations support personnel and facilities must be identified and scheduled, as necessary to accomplish the camera installations.

3.2.1.5 Completion of Work Packages and required documentation to perform work in the AZ Farm. Including camera system installation. ALARA Management Work sheet (AMW) and Radiation Work Permit (RWP) to be approved and in place.

3.2.1.6 Construction of greenhouses and/or other contamination and confinement barriers between the clean areas and contaminated areas shall be accomplished by Hanford Site crafts or contractors. These shall be performed on an as needed basis. 
3.2.1.7 All required training for personnel working at the AZ Farm must be completed.

\subsubsection{PERSONNEL TRAINING/QUALIFICATIONS}

Team members required to enter hazardous/radiation areas in the AZ Farm will fulfill Westinghouse Hanford training requirements for working at those locations.

\subsection{GENERAL SURVEILLANCE ACTIVITIES}

The two camera imaging system will be used to maintain an overview of activities being performed in the 241-AZ-101 double shell tank (DST) during waste retrieval demonstration. Surveillance activities will be done at the direction of the DST Retrieval Responsible Manager and Engineer for the overall project. The primary risers for cameras to be installed into are the $10.16 \mathrm{~cm}$ (4 inch) risers numbered $16 \mathrm{~B}$ and $16 \mathrm{C}$. These risers are located near the center of the DST (tank radius 3.81 meters (12.5 feet)). The inaging system may be installed in any available risers in the AZ-101 tank if the primary choices are found to be unacceptable. The risers currently available in the 241-AZ,-101 tank are listed in Table 1. The camera system installation is not limited to the risers listed.

\section{TABLE 1. AVAILABLE RISERS}

\begin{tabular}{||l|l|l|l|l||}
\hline $\begin{array}{l}\text { RISER } \\
\text { NUMBER }\end{array}$ & $\begin{array}{l}\text { RISER SIZE } \\
(\mathrm{CM})\end{array}$ & $\begin{array}{l}\text { RISER SIZE } \\
\text { (INCHES) }\end{array}$ & $\begin{array}{l}\text { TANK RADIUS } \\
\text { (METERS) }\end{array}$ & $\begin{array}{l}\text { TANK RADIUS } \\
\text { (FT-IN) }\end{array}$ \\
\hline \hline $11 \mathrm{~A}$ & 10.16 & 4 & 9.75 & $32^{\prime}-0^{\prime \prime}$ \\
\hline $13 \mathrm{~A}$ & 10.16 & 4 & 10.59 & $34^{\prime}-9^{\prime \prime}$ \\
\hline $13 \mathrm{~B}$ & 10.16 & 4 & 10.59 & $34^{\prime}-9^{\prime \prime}$ \\
\hline $13 \mathrm{C}$ & 10.16 & 4 & 10.59 & $34^{\prime}-9^{\prime \prime}$ \\
\hline $13 \mathrm{D}$ & 10.16 & 4 & 10.59 & $34^{\prime}-9^{\prime \prime}$ \\
\hline $15 \mathrm{~A}$ & 15.24 & 6 & 10.57 & $34^{\prime}-8^{\prime \prime}$ \\
\hline $15 \mathrm{D}$ & 15.24 & 6 & 10.57 & $34^{\prime}-8^{\prime \prime}$ \\
\hline $15 \mathrm{G}$ & 15.24 & 6 & 10.57 & $34^{\prime}-8^{\prime \prime}$ \\
\hline $15 \mathrm{H}$ & 15.24 & 6 & 10.57 & $34^{\prime}-8^{\prime \prime}$ \\
\hline $15 \mathrm{~J}$ & 15.24 & 6 & 10.57 & $34^{\prime}-8^{\prime \prime}$ \\
\hline $15 \mathrm{~K}$ & 15.24 & 6 & 10.57 & $34^{\prime}-8^{\prime \prime}$ \\
\hline
\end{tabular}




\begin{tabular}{||l|l|l|l|l||}
\hline $\begin{array}{l}\text { RISER } \\
\text { NUMBER }\end{array}$ & $\begin{array}{l}\text { RISER SIZE } \\
(\mathrm{CM})\end{array}$ & $\begin{array}{l}\text { RISER SIZE } \\
\text { (INCHES) }\end{array}$ & $\begin{array}{l}\text { TANK RADIUS } \\
\text { (METERS) }\end{array}$ & $\begin{array}{l}\text { TANK RADIUS } \\
\text { (FT-IN) }\end{array}$ \\
\hline $15 \mathrm{~L}$ & 15.24 & 6 & 10.57 & $34^{\prime}-8^{\prime \prime}$ \\
\hline $16 \mathrm{~B}$ & 10.16 & 4 & 3.81 & $12^{\prime}-6^{\prime \prime}$ \\
\hline $16 \mathrm{C}$ & 10.16 & 4 & 3.81 & $12^{\prime}-6^{\prime \prime}$ \\
\hline $30 \mathrm{~A}$ & 10.16 & 4 & 9.45 & $31^{\prime}-0^{\prime \prime}$ \\
\hline
\end{tabular}

The master control station will be set up in a clean and low exposure area outside the 241-AZ-101 tank farm fence. The camera system will be designed to be remotely operated up to 122 meters ( 400 feet) away from the tank location. The station will contain the following equipment: video tape recorder (VTR), camera control unit (CCU), light control unit (LCU), and video monitor. Equipment will be bagged in plastic, as necessary to minimize contamination for retrieval purposes.

The two camera units will need to be placed into risers by means of a mobile crane. The weight of each camera unit will be approximately $170.10 \mathrm{~kg}$ ( 375 pounds). Once placed, the units will not have to be moved until surveillance activities have been completed or the camera requires maintenance.

\subsection{POST-SURVEILLANCE ACTIVITIES}

As noted in Section 2.2, Surveillance Systems Integration (SSI) will maintain technical responsibility for the camera system equipment at the completion of the project. This will include oversight and input to any removal, decontamination, or storage activities.

All data (video tapes, reports) will be processed by Surveillance Systems Integration (SSI) and forwarded to the cognizant DST Retrieval Projects personnel.

\subsection{RECORDS/REPORTING}

\subsection{RECORDS}

Record-type documents anticipated to be generated for these activities are as follows:
4.1 .1
USQ Screening.

4.1.2 Equipment drawings (i.e., special tooling, etc.) 
4.1.3 Camera System Documents and Criteria (ETP, etc.)

4.1.4 Purchase Specifications and Requisitions.

4.1.5 Work orders.

4.1.6 ATP/OTP and ATR/OTR

4.1.7 Work Packages for the installation of the camera system.

4.1.8 Radiation Work Procedures.

4.1.9 Personnel training/qualification records.

4.1.10 Surveillance Data (VCR tapes, activity reports) and final report.

4.1.11 Personnel exposure records.

4.1.12 Work Authorizations.

4.1.13 ALARA management worksheets and containment certification as required.

All of the above records will be checked prior to program completion by the surveillance Team Lead and cognizant engineer to assure they have been properly prepared. Copies of any written surveillance records and of the videotapes will be forwarded to the responsible oversight organization. Original written documentation will be retained in equipment history with the work package. Original video tapes will be archived in the SSI video library.

\subsection{FINAL REPORTING}

Upon request the SSI Engineer will prepare video tape copies of any surveillance tapes that are in the possession of SSI. Hard copies of specific images on the video tape can be made for the cognizant DST Retrieval Project Engineer upon request. 


\subsection{SAFETY CLASS}

The camera system shall be designed to meet Safety Significant requirements. This Task Plan shall be reviewed and approved in accordance with WHC procedures for a QS system. These requirements have been assigned by the 241-AZ-101 cognizant Engineer for the 241-AZ-101 Tank Farm camera system installation and surveillance activities.

The Electrical Startup and Shutdown System shall be designed to WHC Safety Class electrical requirements. The design shall be reviewed and approved in accordance with WHC procedures for a QS system. This requirement has been assigned to meet startup and shutdown requirements, upon loss of protective cover gas, for equipment in flammable gas atmospheres. The need for this system is contingent if more conservative entry requirements are placed on the waste tank.

\subsection{ALARA MANAGEMENT (PRINCIPLES/PRACTICES)}

ALARA management will be stressed throughout the course of this project by ensuring strict adherence to the following ALARA principles/practices. The following is a summary of some of the proposed methods to be used to reduce personnel exposures. Reference the ALARA manual, WHC-IP-1043.

6.1 Containment will be used, as required, to prevent internal exposure. Time distance and shielding to minimize external exposure and RWP required personal protective clothing tho prevent personnel contamination.

6.2 Maximize effectiveness by using experienced crews for complex tasks (specialize).

6.3 Experienced in-zone personnel will be used.

6.4 Conduct pre-job briefing with all participants, including Radiological Control Technicians, and Operations personnel. Discuss the job to be performed, job specific hazards, general hazards for that location, and egress routes.

6.5 Provide a support person at the step-off pad to expedite requests for assistance from the zone crew.

6.6 Ensure ongoing Radiological Control Technician coverage is available.

6.7 Prepare complete and correct written work procedures and verify procedures on clean mock-ups, when possible. 
6.8 Include radioactive hazard warnings in procedures (radiation beams, hot spots, etc.). Warnings must precede steps in which a hazard may be encountered.

6.9 All equipment taken into contaminated areas will be double bagged or sealed to prevent equipment contamination.

Diligent application of ALARA principles and practices, initial and ongoing support and cooperation of all responsible organizations and, an inherently safe methodology utilized (i.e., remote surveillance by experienced personnel in a clean, low ambient dose rate environment) will contribute to keeping the overall dose rate low. With these factors in mind, the total accumulated dose rate for the camera installation activities could be conservatively estimated to not exceed 0.32 Rem.

Note: The above estimate is based on eight in-zone workers (1 SSI, 2 OPS, 1 RCT, and $4 \mathrm{KH}$ ) taking an estimated dose of $5 \mathrm{mR} / \mathrm{hr}$ for 8 hours per day for a daily total of approximately $320 \mathrm{mR}$ per day. The daily total of $320 \mathrm{mR}$, times 1 workday for camera installation equals an estimated overall dose of approximately $0.32 \mathrm{Rem}$.

\subsection{COST ESTIMATES/SCHEDULE}

\section{$7.1 \cos T$}

The following is a breakdown of the estimated cost for the surveillance phase of this project.

$$
\begin{aligned}
& \text { Manpower ---_---- } \$ 73,600.00 \\
& \text { Equipment ------------ } \$ 287,676.00
\end{aligned}
$$

An itemized cost breakdown is shown in Appendix A.

\subsection{SCHEDULE}

The camera system is to be installed and ready for inspections by July 28,1996 . Process testing is scheduled to begin by September 1996. The following are some of the milestones set for this project: 


\begin{tabular}{|l|l|}
\hline DATE & ACTIVITY \\
\hline March 22,1995 & Engineering Task Plan (ETP, rev. 0) Issued \\
\hline \hline April 26,1995 & 30\% Design Review of the System Specification. \\
\hline June 21, 1995 & $90 \%$ Design Review of the System Specification. \\
\hline August 2,1995 & System Procurement Specification Issued \\
\hline March 8,1996 & Revision of Engineering Task Plan (ETP, rev. 1) for Review \\
\hline June 28,1996 & Submittal of Acceptance Test Procedure (ATP) for Review \\
\hline July 1,1996 & Camera System Delivery Date. \\
\hline July 8, 1996 & Setup and Functionally Check Camera System \\
\hline July 15, 1996 & Perform ATP on Camera System \\
\hline July 22, 1996 & Camera System Installation. \\
\hline
\end{tabular}

\subsection{REFERENCES}

8.1 WHC-CM-3-5, "Document Control and Records Management Manual," Section 12.7 Rev. 0, Change 4, "Approval of Environmental, Safety , and Quality Affecting Documents" WHC, Richland, Washington, April 10, 1996.

8.2 WHC-IP-1026, "Engineering Practice Guidelines," Westinghouse Hanford Company, Richland, Washington, May 27, 1994.

8.3 WHC-CM-8-8, "Job Control System," Site Maintenance Integration \& Control, Westinghouse Hanford Company, Richland, Washington, August 11, 1988.

8.4 HSRCM-1, "Hanford Site Radiological Control Manual, Revision 2", Westinghouse Hanford Company, Richland Washington, December 9, 1994.

8.5 H-2-67314 "Plan Tank 101 Penetrations \& Schedule 241-AZ Tank Farm."

8.6 WHC-SD-RE-TI-093, Rev 3, page 153, "Double-shell Underground Waste Storage Tanks Risers."

8.7 WHC-CM-4-46, "Safety Analysis Manual," Section 9.0, Rev 2, February 26, 1996.

8.8 WHC-IP-1043, "WHC Occupational ALARA Program," Rev. 2, October 27, 1995. 


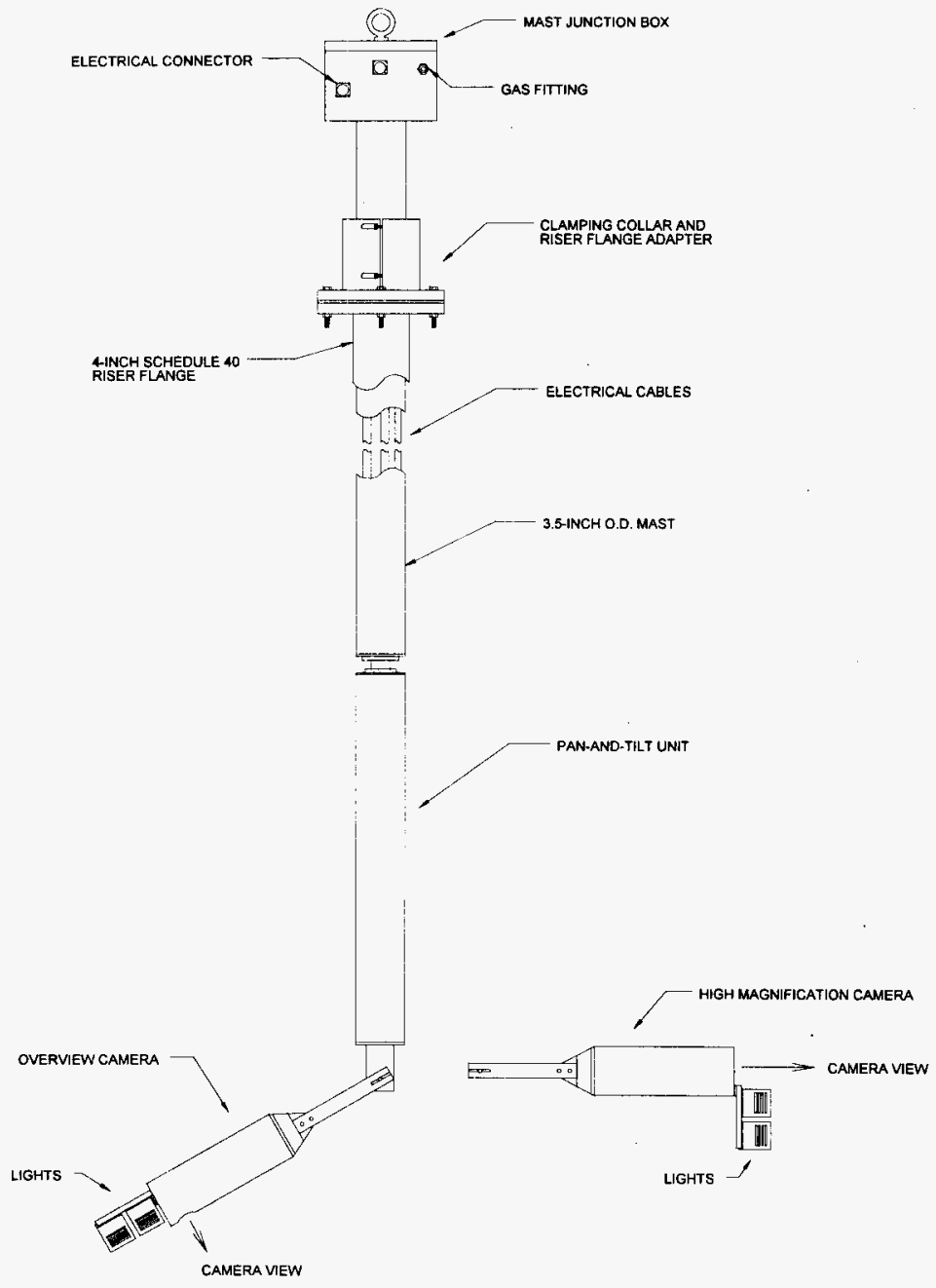

FIGURE 1. DRAWING OF CAMERA AND MAST ASSEMBLY 


\section{SYSTEM OVERVIEW}

CAMERA 1 (HIGH MAGNIFICATION)

FAN, TIL.T, ZEDM

LIGHTS

XS MAGNIFICATIDN
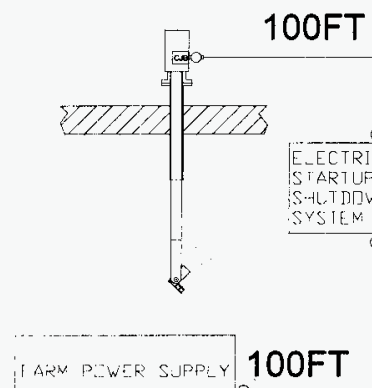

GAS SJPP:

(AIR CDMPR SSDR)

\section{LEGEND}

CAMERA JUNCTION BOX

- CONNECTOR
CAMERA 2 (OVERVIEW)

PAN, TILT, ZUUMM

LIGHTS

SHIELDED/PRISMED

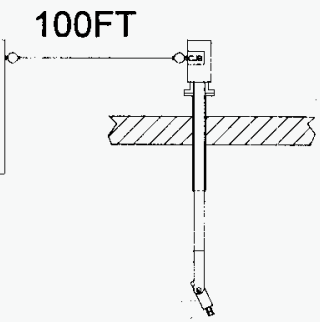

FIGURE 2. GENERAL SYSTEM CONFIGURATION 


\section{AZ-101, AVAILABLE RISERS}

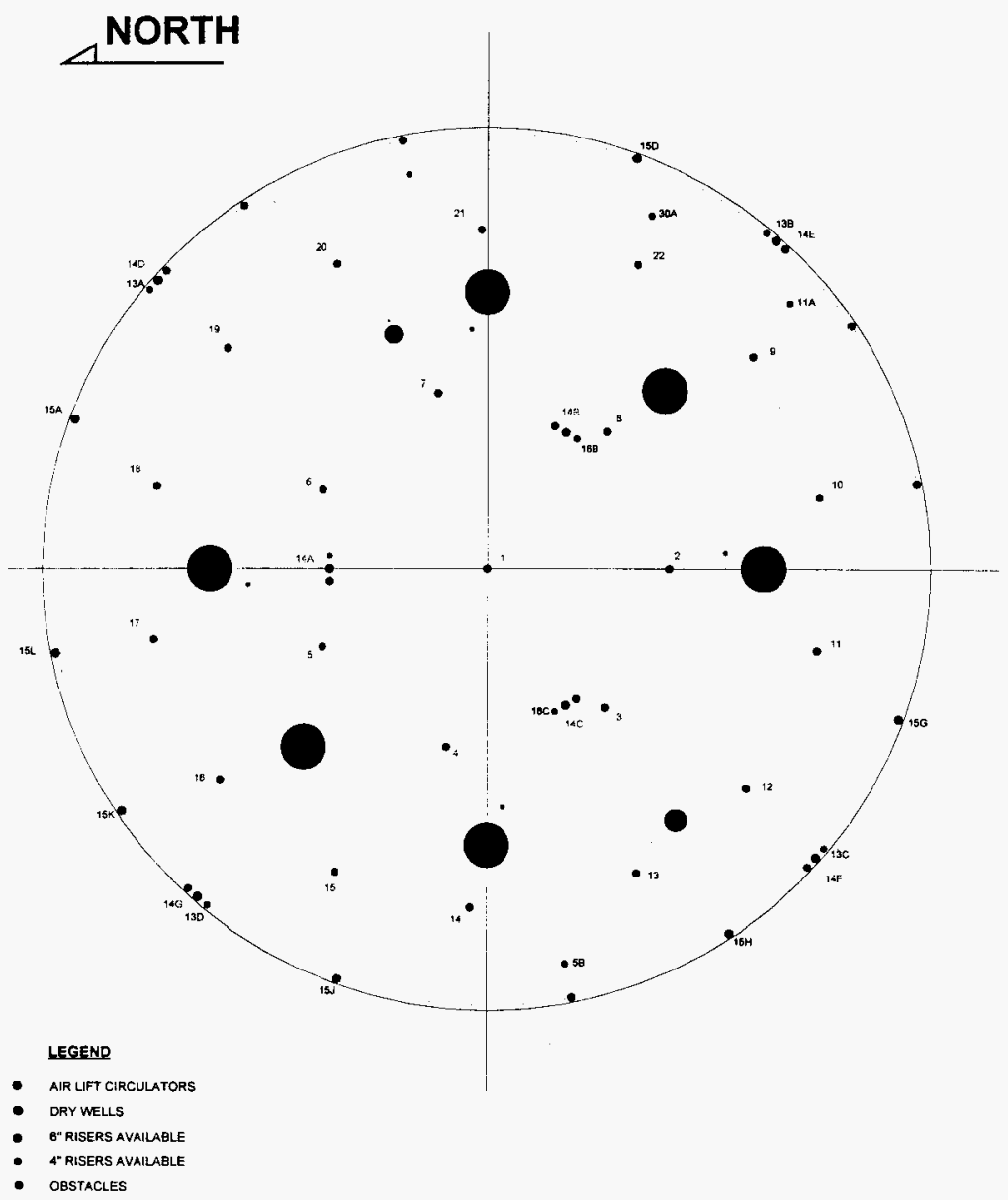

FIGURE 3. AVAILABLE VIEWING RISERS 


\section{APPENDIX A - COST ESTIMATE}

\subsection{LABOR}

WORK DAYS

1.1 Camera Inspection Engineering Task Plan (ETP)

20.0 Eng.

Prepare draft

Internal review

Distribute for comment

Incorporate comments

Issue final draft

1.2 Procurement of Materials/Equipment

Select materials

Prepare Camera Specifications

Prepare purchase requisitions

Obtain authorization signatures

Interface with vendors/buyers

Track purchase orders

Receive/inspect/test materials

22.0 Eng.

1.3 Revise Engineering Task Plan (ETP)

Prepare draft

Internal review

Distribute for comment

Incorporate comments

Issue final draft

18.0 Eng.

1.3 Designing Additional Accessories/Tooling

Design/fabricate accessories/tooling

Drawings

10.0 Eng.

1.4 System Acceptance Testing

Prepare ATP

Initial system testing/training

Assemble system

Perform acceptance testing (ATP)

Modify/resolve problems

30.0 Eng.

ETN-95-0038 
1.5 Perform inspections

Camera reconnaissance

Hold pre-job meetings

Set up equipment/remove equipment

Transport equipment and personnel

Install Camera System

Perform Surveillance Activities

40.0 Eng.

1.6 Reporting

Write reports as required

5.0 Eng.

1.7 Editing/Copying of Video Tapes

Copy and edit video tapes

15.0 Eng.

Total work days: 160.0 Eng.

Cost Per Workday (OH 22.5\% and G\&A/SWS 19\%) X X

MANPOWER TOTAL $\$ 73,600.00$

2.0 MATERIALS, TRAVEL, AND TRAINING

2.1 Miscellaneous Material Costs and Expenses

Video tapes

$\$ \quad 50.00$

Miscellaneous on Site Costs

$\$ 5,000.00$

Compressor and purge hosing

$\$ 4,000.00$

Electrical Shutdown System

$\$ 7,500.00$

2.2 Travel to and from work site

$\$ 500.00$

2.3 Training (required by WHC)

$\$ 2,000.00$

MATERIAL COST $\$ \$ 19,050.00$

Procurement Cost $(11.9 \%) \quad \$ 2.267 .00$

EQUIP/MATERIAL TOTAL $\$ \mathbf{2 1 , 3 1 7 . 0 0}$

ETN-95-0038 
An itemized component breakdown and cost will be available upon request.

\subsection{TOTALS}

MANPOWER TOTAL

EQUIP/MATERIAL TOTAL

CAMERA SYSTEM TOTAL
$\$ 73,600.00$

$\$ 21,317.00$

$\$ 266.359 .00$

\section{GRAND TOTAL}

All values are estimated costs. All equipment taken into a Radiation zone shall be double bagged or sealed as necessary to minimize contamination possibilities. All equipment utilized during this surveillance inspection shall be purchased by DST Retrieval Projects. 
DISTRIBUTION SHEET

\begin{tabular}{|c|c|c|c|c|c|}
\hline \multirow{2}{*}{$\begin{array}{l}\text { To } \\
\text { Distribution }\end{array}$} & \multirow{2}{*}{\multicolumn{3}{|c|}{$\begin{array}{l}\text { From } \\
\text { Surveillance Systems } \\
\text { Integration }\end{array}$}} & \multicolumn{2}{|l|}{ Page 1 of 1} \\
\hline & & & & \multicolumn{2}{|c|}{ Date $6 / 28 / 96$} \\
\hline \multicolumn{4}{|l|}{$\begin{array}{l}\text { Project Title/Work Order } \\
\text { PROJECT W151, Engineer }\end{array}$} & \multicolumn{2}{|l|}{ EDT No. } \\
\hline $\begin{array}{l}\text { PROJECT W151, Engineer } \\
\text { Rev. } 1 \text {, for the } 241-A Z\end{array}$ & $\begin{array}{l}\text { Ian WHC-SD-W151 } \\
\text { ction Camera Sy }\end{array}$ & $\begin{array}{l}\text {-ETP-001, } \\
\text { stem }\end{array}$ & & \multicolumn{2}{|c|}{ ECN No. 601559} \\
\hline Name & MSIN & $\begin{array}{l}\text { Text } \\
\text { With All } \\
\text { Attach. }\end{array}$ & Text Only & $\begin{array}{l}\text { Attach./ } \\
\text { Appendix } \\
\text { Only }\end{array}$ & $\begin{array}{l}\text { EDT/ECN } \\
\text { Only }\end{array}$ \\
\hline $\begin{array}{l}\text { RK Brown } \\
\text { RE Clayton } \\
\text { EM Nordquist } \\
\text { RS Robinson } \\
\text { DB Smet } \\
\text { GR Tardiff } \\
\text { Centeal Les }\end{array}$ & $\begin{array}{l}H 5-68 \\
S 2-48 \\
S 2-48 \\
N 1-46 \\
N 1-46 \\
S 5-05 \\
A 3-88\end{array}$ & $\begin{array}{l}1 \\
1 \\
1 \\
2 \\
1 \\
1 \\
1\end{array}$ & creig & & \\
\hline
\end{tabular}

